\title{
„Upojenie jako triumfalne wtargnięcie w nas rośliny": obietnice i niebezpieczeństwa roślinnej seksualności
}

Joanna Bednarek

TEKSTY DRUGIE 2018, NR 2, S. 186-205

DOI: $10.18318 /$ td.2018.2.12

\section{M} ądrość roślin: nawet dla tych przyjmujących postać korzenną zawsze istnieje jakieś zewnętrze, w którym tworzą one kłącze z pewnymi rzeczami - $z$ wiatrem, ze zwierzęciem, z człowiekiem" - piszą Deleuze i Guattari na samym początku Tysiąca plateau. Kilka zdań później radzą, by „postępować jak rośliny"1 - czyli wyzbyć się tych sposobów organizacji naszych ciał i podmiotowości, które decydują o człowieczeństwie: indywidualizmu, tożsamości gatunkowej (,człowiek" jako istota odrębna od reszty bytu), seksualności pojmowanej jako zdenaturalizowana i naznaczona brakiem. „Postępować jak" nie oznacza jednak: naśladować roślinę (jak mielibyśmy to robić, skoro tak bardzo się od niej różnimy?), ale stawać-się-rośliną: zarazić się roślinną obcością na poziomie molekularnym, wytworzyć pewne struktury odpowiadające organizacji roślinnej na gruncie ludzkiej organizacji ciała i pragnienia, dążąc do wypracowania
Joanna Bednarek

- dr, filozofka,

pisarka, tłumaczka, członkini redakcji „Praktyki Teoretycznej.". Autorka m.in. książek: Polityka poza formą. Ontologiczne uwarunkowania poststrukturalistycznej filozofii polityki, Linie kobiecości. Jak różnica płciowa przekształciła literaturę i filozofię? ¡Życie, które mówi. Nowoczesna wspólnota i zwierzęta.

1 G. Deleuze, F. Guattari Tysig̨c plateau, [brak nazwiska tłumacza], Fundacja Bęc Zmiana, Warszawa 2015, s. 12-13. 
etyki i polityki nie-ludzkiej, amoralnej i afirmującej życie². Stawanie-się-rośliną stanowi więc proces bliski znacznie lepiej opisanemu (zarówno przez samych filozofów, jak i licznych komentatorów i komentatorki³) stawania-się-zwierzęciem. Więcej: proces w pewnym sensie bardziej radykalny od wyżej wymienionego.

Deleuze i Guattari ostrzegają wprawdzie przed traktowaniem poszczególnych stawań-się jako uporządkowanych hierarchicznie, od najmniej radykalnego stawania-się-kobietą, po najbardziej radykalne stawanie-się-niedostrzegalnym: „błąd, którego powinniśmy się wystrzegać, dotyczy wiary w pewien rodzaj porządku logicznego w ramach amfilady, w owych przejściach czy też przekształceniach. Czymś nadto jest już postulować pewien porządek biegnący od zwierzęcia do rośliny, następnie od cząstek do molekuł. Każda wielość jest symbiotyczna i łączy w swym stawaniu się zwierzęta, rośliny, mikroorganizmy, szalone cząstki, całą galaktykę"4. Nie sposób jednak zaprzeczyć, że sami prowokują takie odczytanie, choćby tylko poprzez częste przywoływanie tak właśnie uporządkowanego szeregu: stawanie-się kobietą, dzieckiem, zwierzęciem, rośliną, minerałem.... ${ }^{5}$ Dlatego choć wszystkie stawania się są tak samo radykalne, ponieważ umożliwiają odejście od opresyjnego wzorca podmiotowości, każde z nich ma własną, swoistą przestrzeń działania, obszar, który radykalizuje i deterytorializuje najbardziej (jak płeć w przypadku stawania-się-kobietą czy człowieczeństwo w przypadku stawania-się-zwierzęciem). Roślinie przypada pod tym względem miejsce szczególne, ponieważ umożliwia ona jednoczesne postawienie dwóch problemów kluczowych dla etyki deleuzoguattariańskiej: nieedypalnej, nienaznaczonej brakiem seksualności i odejścia od antropocentryzmu.

Analizy problematyki „roślinnej” u Deleuze’a i Guattariego były przez długi czas podporządkowane przeciwstawieniu drzewa i kłącza otwierającym Tysiąc plateau ${ }^{6}$ : drzewo funkcjonuje w nim jako model organizacji

2 Co dla autorów Kapitalizmu i schizofrenii jest równoznaczne z afirmacją, w pewnych sytuacjach, destrukcji i śmierci; zob. P. MacCormack After Life, w: The Animal Catalyst: Towards Ahuman Theory, ed. by P. MacCormack, Bloomsbury, London 2014.

3 Zob. np.: R. Braidotti Metamorphoses, Polity Press, Cambridge 2002; A. Beaulieu The Status of Animality in Deleuze's Thought, "Journal for Critical Animal Studies" 2011 Vol. 9, No. 1/2; Deleuze and the Animal, ed. by C. Gardner, P. MacCormack, Edinburgh University Press, Edinburgh 2017.

4 G. Deleuze, F. Guattari Tysiąc plateau, s. 302.

5 Tamże, s. 126, 138-9, 301, 329, 508.

6 A. Marzec Roślinna filozofia (czyli myślenie roślinności), "Czas Kultury” 2008 nr 5. 
dychotomicznej, scentralizowanej i opartej na przeciwieństwach, kłącze zaś jako model organizacji zdecentralizowanej, modułowej i elastycznej. Rośliny są tu jednak raczej abstrakcyjnymi metaforami niż punktem wyjścia do refleksji na temat statusu różnych żywych istot; pozostając przy tym motywie, można mówić o roślinach u Deleuze'a i Guattariego, w ogóle nie kwestionując antropocentryzmu. Zmienił to niedawny „zwrot roślinny” w humanistyce, który ukazał dzieło francuskich teoretyków jako pionierskie pod względem nieantropocentrycznego ujęcia „bytu roślinnego" w filozofii .

Wpisuje się on w szerszy nurt - obejmujący posthumanizm, animal studies czy nowy materializm - dążący do wypracowania pojęć i ram teoretycznych pozwalających na ujmowanie wszystkich żywych istot (co być może obejmuje lub będzie w niedalekiej przyszłości obejmować również maszy$\left.n y^{8}\right)$ jako obdarzonych sprawczością i zasługujących na nieinstrumentalne traktowanie ze strony człowieka. Część tych prób polega na wykorzystaniu pojęć i dyskursów tradycyjnie obejmujących tylko ludzi - przykładem może być uznanie zwierząt za istoty posiadające interesy lub będące „podmiotami życia"', a także postulaty, znajdujące już odbicie w rozstrzygnięciach niektórych instytucji państwowych i międzynarodowych, uznania zwierząt i roślin za podmioty praw ${ }^{10}$. Prowokacyjny tytuł książki Matthew Halla, Plants as Persons, ukazuje zarówno praktyczny radykalizm tych postulatów, jak i ich teoretyczną zachowawczość, fakt wykorzystywania przez nich istniejących dyskursów: chodzi o to, by prawa, nie tylko dotyczące ludzi w sensie empirycznym, ale i „skrojone na miarę człowieka” (bo implikujące rozumność czy indywidualizm), rozciągnąć na istoty dotąd uważane za nierozumne i znajdujące się poza wspólnotą polityczną". Stanowi to rewolucję ideologiczną na miarę oświeceniowej idei równości wszystkich ludzi i może mieć

7 K.L.F. Houle Animal, Vegetable, Mineral: Ethics as Extension or Becoming? The Case of Becoming -Plant "Journal for Critical Animal Studies" Vol. 9, No. 1/2; H. Stark Deleuze and Critical Plant Studies, w: Deleuze and the Non/Human, ed. by J. Roffe, H. Stark, Palgrave Macmillan, London 2015. G. Bateson Umysłi przyroda. Jedność konieczna, przeł. A. Tanalska-Dulęba, PIW, Warszawa 1996.

9 J. Bednarek Życie, które mówi, Fundacja na Rzecz Myślenia im. Barbary Skargi/PWN Warszawa 2017, s. 19-20. M. Marder Czy rośliny powinny mieć prawa?, przeł. K. Kornas, "Znak” 2016 nr 733, http://www. miesiecznik.znak.com.pl/czy-rosliny-powinny-miec-prawa/ (7.12.2017).

11 J. Stanescu Beyond Biopolitics: Animal Studies, Factory Farms, and the Advent of Deading Life, "PhaenEx" 2013 Vol. 8, No. 2; D. Wadiwel The War against Animals. Domination, Law and Sovereignty " "Griffith Law Review” 2009 Vol. 18, No. 2. 
niezwykle doniosłe praktyczne skutki; zarazem jednak oznacza, że nie kwestionujemy samego człowieczeństwa i jego statusu wzorca podmiotowości. Dlatego drugim, równie istotnym aspektem przedsięwzięcia są dokonywane (głównie na gruncie teorii „kontynentalnej”) próby przemyślenia, co oznacza dla człowieczeństwa włączenie nie-ludzi do wspólnoty. W kwestii roślin reprezentatywne dla tego podejścia są zainspirowane głównie dekonstrukcją, ale wykorzystujące w zasadzie wszystkie poststrukturalistyczne analizy dotyczące decentralizacji podmiotu, prace Michaela Mardera. Jak podkreśla, jego celem nie jest negowanie zasadności mówienia o prawach czy godności roślin, ale zakorzenienie tych praktycznych innowacji w innowacjach teoretycznych - nie sposób bowiem mówić o roślinach jako bytach, wobec których mamy obowiązki etyczne, nie kwestionując dotychczasowych ujęć człowieczeństwa i podmiotu, nie „dehumanizując ludzkiego myślenia”"12. Rośliny pomagają nam „odmyśleć” wiele założeń dotyczących świadomości, podmiotowości i racjonalności - choć nie można im odmówić tych cech, przyjmują one w ramach "roślinnego bytu" postać skrajnie odmienną od tej, do której jesteśmy przyzwyczajeni. Jej „modułowa” budowa ${ }^{13}$, zależność od żywiołów i niemal niedostrzegalny dla ludzkiego oka ruch sprawiają, że „roślina, w samym swoim bytowaniu, dokonuje przeżywanej destrukcji metafizyki" ${ }^{4}$. Dzięki temu możliwa staje się wspólnota obejmująca zarówno ludzi i zwierzęta, jak rośliny, oparta na nieinstrumentalnym traktowaniu wszystkich należących do niej bytów - nie chodzi rzecz jasna o to, by przestać jeść rośliny, ale by uznać nasz (niespłacalny) dług wobec nich poprzez ograniczenia konsumpcji, unikanie upraw monokulturowych i modyfikacji genetycznych ${ }^{15}$.

Deleuzjańskie inspiracje „zwrotu roślinnego” wpisują się w taki właśnie projekt decentralizacji, myślenia w kategoriach powiązań międzygatunkowych, nie zaś oddzielonych od siebie jednostek, gatunków i intuicji, że poważne potraktowanie naszych związków z roślinami oznacza stanie się czymś innym niż człowiekiem, wyjście z antropocentrycznej izolacji, nawiązanie kontaktu z zewnętrzem: „Paradoksalnie, aby siebie odzyskać, musimy

M. Marder Plant-Thinking. A Philosophy of Vegetal Life, Columbia University Press, New York 2013, s. 10.

Zob. A. Trewavas Aspects of Plant Intelligence , "Aspects of Botany” 2003 Vol. 92, No. 1, s. 10. 
zagubić się lepiej, ucząc się, jak rosnąć na zewnątrz"16. Musimy stać-się-rośliną. Jednak niekoniecznie oznacza to, przynajmniej dla Mardera, rezygnację z człowieczeństwa. Chce on w ten sposób oddalić niebezpieczeństwo iluzorycznej identyfikacji z rośliną, która oznaczałaby jego zdaniem tylko narzucenie jej ludzkich kategorii" ${ }^{17}$. Stawanie się nie polega jednak wcale na stopieniu się w jedno: to precyzyjnie ustrukturyzowany proces, wskutek którego zarówno człowiek, jak i to, czym człowiek się staje, ulegają transformacji ${ }^{18}$. Jego stawką jest nie tylko uznanie odrębności rośliny, ale zmiana całego układu, obejmującego człowieka i jego innych. Choć nie sposób przewidzieć wyniku stawania się, jedno jest pewne: zawsze obejmuje on utratę człowieczeństwa (rozumianego przez Deleuze'a i Guattariego jako kategoria istotowo patriarchalna i rasistowska, której nie warto bronić). Bliższe rozpatrzenie roli, jaką odgrywają autorzy Kapitalizmu i schizofrenii w „zwrocie roślinnym" wymaga więc, jak sądzę, wysunięcia na plan pierwszy zagadnienia szczególnego charakteru ich antyhumanizmu. Ujawnia się on z wyjątkową precyzją w problematyce seksualności: dla Deleuze'a i Guattariego (alienujące, autorytarne) człowieczeństwo i (edypalna, naznaczona brakiem) seksualność tworzą splot, który pozwala przeciąć właśnie kwestia seksualności roślinnej - nietożsamej z seksualnością roślin, jako że, choć to one są pod tym względem wzorem dla ludzi, również ludzie mogą kształtować swoje pragnienie na sposób roślinny.

Porównanie tej perspektywy z podejściem Luce Irigaray, również zaangażowanej w filozoficzną refleksję nad roślinami, ukazuje, o co toczy się gra. Wedle Irigaray rośliny są nam niezbędne - ale po to, byśmy mogli stać się bardziej ludźmi czy też lepszymi ludźmi: „To przez [through] tlen, jakiego dostarczają nam rośliny, przychodzimy na świat i możemy żyć dzięki oddychaniu. Roślinne życie w pewnym sensie koresponduje z etapem, przez który [through] musimy przejść, by móc rozwinąć się jako istoty ludzkie"19. Należy więc uznać dług - ale rośliny, jako ucieleśnienie „natury”, pozostają zasobem, z którego człowiek czerpie, by się ukonstytuować w swojej odrębności.

Tamże, s. 167.

Tamże, s. 196.

J. Bednarek The Oedipal Animal? Companion Species and Becoming, w: Deleuze and the Animal.

L. Irigaray, C. Davis Rozmowa z legendarną filozofkq i aktywistkq̨ Luce Irigaray, "Nowa Orgia Myśli” http://nowaorgiamysli.pl/index.php/2017/11/16/rozmowa-z-legendarna-filozofka-i-aktywistkaluce-irigaray/ (8.12.2017). 
Produkując tlen, rośliny dostarczają powietrznego łożyska ${ }^{20}$, w którym człowiek, czasowo zredukowany do statusu płodu, może się okresowo regenerować, by zyskiwać siły. Symbioza z roślinami to konieczny etap naszego rozwoju - ale etap, który należy przekroczyć, wychodząc ku drugiemu człowiekowi: „dojrzałość wymaga od nas, byśmy przyjęli to, że jako ludzkie istoty jesteśmy indywiduami i odkryli, jak możemy stać się źródłem szczęścia dla nas samych, dla innego/innych, w naszym współistnieniu. Jeśli nie osiągniemy tego etapu, to popadniemy w ryzyko uznania natury za naszą matkę, od której możemy otrzymać wszystko bez konieczności odwzajemnienia czegokolwiek. To nie z naturą mamy doświadczać prawdziwej wzajemności, lecz z kimś, kto dzieli naszą kondycję ludzką i pozostaje w stosunku do nas jednostką autonomiczną"21.

Ale dlaczego właściwie natura ma być dla nas matką? Dlaczego mamy redukować ją do figur zaczerpniętych z Freudowskiego trójkąta rodzinnego? Istnieje oczywiście długa tradycja używania metafor macierzyńskich przy opisywaniu natury; dziwi jednak fakt, że Irigaray, jako jedna z fundatorek filozofii feministycznej, odtwarza tę tradycję tak bezrefleksyjnie. Dzieje się tak, ponieważ rozważania na temat roślin stanowią część proponowanej przez nią na późniejszym etapie twórczości ontologii różnicy płciowej. Różnica owa to "cięcie, luka, nieprzekraczalna negatywność" ${ }^{22}$ - nieciągłość charakterystyczna dla ludzkiego życia i stanowiąca o jego wyjątkowości. „Stawanie się człowiekiem oznacza zdolność do przyjęcia niedającej się przezwyciężyć negatywności naszej płciowości, rozumianej jako granica, jaką życie wyznacza samo sobie"23. Dzięki różnicy płciowej (określenie to jest dość mylące, ponieważ w praktyce chodzi o dychotomię, która jest źródłem wszystkich innych, wtórnych ontologicznie, różnic) wiemy, że nie jesteśmy całością, nie jesteśmy wszystkim; naznacza nas oddzieleniem, w przeciwieństwie do zwierząt i roślin, które istnieją w świecie, by przywołać stare powiedzenie Bataille’a, „jak woda w wodzie"24. Oddzielenie to było w licznych filozofiach XIX i XX wieku, od Hegla po Heideggera, ujmowane przez pryzmat śmiertelności - na życie, a wcześniej na materię, opisywane za pomocą upłciowionych meta-

L. Irigaray, M. Marder Through Vegetal Being, s. 28.

L. Irigaray, C. Davis Rozmowa...

L. Irigaray, M. Marder Through Vegetal Being, s. 12.

L. Irigaray, C. Davis Rozmowa...

G. Bataille Teoria religii, przeł. K. Matuszewski, KR, Warszawa 1996, s. 24. 
for, filozofowie zawsze patrzyli z pewną podejrzliwością. Celem filozofki jest zastąpienie tego jednostronnego skupienia na śmierci, odpowiedzialnego za patriarchalizm i instrumentalne podejście do natury, ontologią, która zapewni poszanowanie tego, co kobiece i dla natury, zajmującej symbolicznie miejsce tego, co kobiece.

„To przy [through] pomocy świata roślin możemy przejść z jednej fazy kulturowej do innej bez ryzyka destrukcji czy śmierci, co jest szalenie istotne w nihilistycznej epoce, w jakiej żyjemy. Żywię również głęboką nadzieję, że świat roślin może działać jako żywy pośrednik pomiędzy logiką tego, co męskie, która preferuje relacje podmiotowo-przedmiotowe, a logiką tego, co kobiece, która uprzywilejowała relacje podmiotowo-podmiotowe"25. Zdaniem Irigaray ma to uwolnić naszą kulturę od destrukcyjności związanej z zafiksowaniem na śmierci, która związana jest z patriarchalnym (czyli uprzywilejowującym to, co męskie) charakterem zachodniej kultury. Nie sposób jednak nie dostrzec, że różnica płciowa wykonuje tu dokładnie tę samą pracę, którą u Heideggera, Bataille’a czy Lacana wykonuje śmierć. Przykład psychoanalizy pokazuje zresztą, że zachodnia nowoczesność wiąże ze sobą ściśle seks i śmierć: nie sposób wspomnieć tej pierwszej, by na horyzoncie nie pojawił się drugi, i na odwrót. Człowieczeństwo, seks i śmierć tworzą triadę, której nie sposób rozmontować, zastępując śmierć różnicą płciową. Przyznanie tej różnicy, pojmowanej jako dychotomia tego, co żeńskie i tego, co męskie, statusu luki czy też pęknięcia określającego ludzki byt, oznacza powielanie heteronormatywnej mistyki płci, będącej jednocześnie mistyką negatywności i skończoności ${ }^{26}$.

25

26 psychoanalizy i próbę zarysowania nieesencjalistycznej ontologii kobiecości (zob. K. Szopa Psychoanaliza jako "Martwy punkt odwiecznej iluzji symetrii", czyli Irigaray spotyka Deleuze'a i Guattariego, „Praktyka Teoretyczna” 2017 nr 3 (25); http://www.praktykateoretyczna. pl/katarzyna-szopa-psychoanaliza-jako-martwy-punkt-odwiecznej-iluzji-symetrii-czyliirigaray-spotyka-deleuzea-guattariego/ (5.12.2017)), późniejsza ewolucja jej teorii w stronę ontologii różnicy płciowej nie spełnia moim zdaniem obietnicy złożonej w tych wcześniejszych dziełach, zbliżając się niebezpiecznie do apologii heteronormatywnej męskości i kobiecości takiej, jakie znamy je dzisiaj. Liczne komentatorki proponują wprawdzie interpretacje podkreślające, że różnica płciowa nie jest kategorią z porządku empirycznego, odsyłającą do kobiet i mężczyzn jako konkretnych (w tym biologicznych) bytów; stwarza raczej przestrzeń, w której może ukazać się wielość płciowych (i nie tylko) ekspresji (zob. K. Szopa, tamże; K. Szopa Filozoficzne herbarium Luce Irigaray, Nowa Orgia Myśli, http://nowaorgiamysli.pl/index. php/2017/11/18/filozoficzne-herbarium-luce-irigaray/ (5.12.2017)), Mimo to sądzę, że uprzywile- 
Ujęcie seksualności w Kapitalizmie i schizofrenii ma właśnie dostarczyć realnej alternatywy dla tego uwikłania, każącego nam myśleć „,kobieta i mężczyzna” (czy wręcz "matka i ojciec”), kiedy myślimy o seksie, a „śmierć i skończoność", kiedy myślimy o człowieczeństwie. Rośliny są w tym kontekście ważnymi sojuszniczkami Deleuze'a i Guattariego. Nie są to jednak rośliny jako dobroczynne dawczynie tlenu, istoty w przeciwieństwie do nas bezpłciowe, czy też upłciowione na zaledwie empirycznym, nie zaś ontologicznym poziomie (jeśli rośliny maja duszę, wydaje się ona nie mieć ptci, jak ujmuje to Irigaray $\left.^{27}\right)$. Marder słusznie kwestionuje ten wybór teoretyczny, zwracając uwagę na to, że odmienność seksualności roślin może nieść ważne konsekwencje również dla nas. „Jak Twoim zdaniem powinniśmy myśleć o seksualności roślin? - pyta. Na czym polega jej istotność dla ludzkiej różnicy płciowej? Mam na myśli to, że płynność, różnorodność i plastyczność roślinnej seksualności, w obrębie której wiele roślin jest obupłciowych, inne mogą zmieniać płeć podczas swojego życia, a jeszcze inne rozmnażają się bezpłciowo"28. Rozmnażanie się roślin nie wymaga partnera „przeciwnej płci”, ale po prostu innej rośliny - lecz także wielu innych bytów. Rośliny nie uwodzą partnerów swojego gatunku, ale np. owady - słynna symbiotyczna para osy i orchidei opisana w „Kłączu” stanowi dobry przykład ${ }^{29}$. Ich seksualność jest więc $\mathrm{z}$ istoty nieheteronormatywna i perwersyjnie międzygatunkowa. Pozostaje też ściśle uzależniona od żywiołów: jak komentuje Monika Bakke, „[w] życiu płciowym [...] rośliny kwiatowe powszechnie wykorzystują ruch pochodzący z otoczenia, czyli na przykład wiatr, ale też ruch wody czy zwierzą $t^{\prime \prime 30}$. Roślina, żeby uprawiać seks, potrzebuje całego świata - a przynajmniej sporej jego części, złożonej z różnorodnych bytów, należących do odmiennych porządków - tego, co nieożywione, innych roślin i zwierząt.

Deleuze i Guattari wykorzystują te fakty dotyczące odmienności roślin, interpretując dwie perspektywy, w jakich pojawia się homoseksualizm na

jowuje ona heteroseksualność, czyniąc ją mechanizmem odpowiedzialnym za konstytuowanie się człowieczeństwa; nawet jeśli unika biologicznego redukcjonizmu, zastępuje go redukcjonizmem ontologicznym. Tamże, s. 112.

G. Deleuze, F. Guattari Tysiq̨c plateau, s. 10-11; M. Bakke Rozkwitający seks. Roślinne transpozycje w pracach Natalii LL iZofii Kulik, w: Natalia LL. Nie tylko Sztuka konsumpcyjna, red. A. Jakubowska, Centrum Sztuki Współczesnej Zamek Ujazdowski, Warszawa 2016, s. 59. 
kartach W poszukiwaniu straconego czasu. Jedna z nich to perspektywa homoseksualności jako zła, transgresji i winy, wykroczenia przeciwko normalności: ucieleśnia ją obraz panny de Vinteuil pozwalającej, by kochanka napluła na zdjęcie jej ojca. Jednak „pozorny wątek winy, jaki spotykamy u Prousta, splata się z wątkiem całkowicie odmiennym, negującym poprzedni, to znaczy z roślinną niewinnością i szczerością, jaka wynika z odgrodzenia się płci" ${ }^{31}$. Proces uwodzenia pszczoły przez kwiat (również gatunek orchidei!) zostaje zestawiony z seksualnymi podchodami barona de Charlus i Jupiena ${ }^{32}$.

Perspektywie winy towarzyszy więc perspektywa seksualnej nienormatywności jako osobnego, nieludzkiego świata, w którym dokonują się nieustanne permutacje połączeń tego, co „męskie” i tego, co „żeńskie”, funkcjonujących jako abstrakcyjne, molekularne własności, nie określające poszczególnych ciał, ale ich wielorakie potencjalności:

wątek roślinny, niewinność kwiatów, przynosi nam jeszcze inny przekaz, inny kod: każda osoba jest biseksualna, każdy ma dwie płcie, ale odgrodzone od siebie i nieskomunikowane; mężczyzna to tylko ten, u którego część męska przeważa statystycznie, kobietą jest ta, u której statystycznie przeważa część żeńska. Dlatego na poziomie elementarnych kombinacji należy wprowadzić co najmniej parę mężczyzn i parę kobiet, aby otrzymać wielość, w której nawiązane zostają poprzeczne linie komunikacji, połączenia obiektów częściowych z przepływem: część męska u mężczyzny komunikuje się z żeńską częścią kobiety, ale również z jej częścią męską lub z częścią żeńską innego mężczyzny czy wreszcie z jego częścią męską itd. ${ }^{33}$

Dzięki roślinom zyskujemy dostęp do seksualności wolnej od rozróżnień na mężczyznę i kobietę, normę i patologię, winę i niewinność, naturę i to, co nienaturalne, „człowieka” i całą resztę świata. „Nie chodzi już o szukanie winnego, bowiem wina nie może uczepić się tych kwiatów. Wykluczającej alternatywie „albo... albo" przeciwstawia się „lub” kombinacji i permutacji,

G. Deleuze, F. Guattari Anty-Edyp, przeł. T. Kaszubski, Wydawnictwo Krytyki Politycznej, Warszawa 2017, s. 49-50. por. G. Deleuze Proust i znaki, przeł. M.P. Markowski, słowo/obraz terytoria, Gdańsk 2000, s. 15-16. 
w których różnice sprowadzają się do tego samego, pozostając przy tym różnicami" ${ }^{34}$.

Rośliny, w odróżnieniu od zwierząt, są szczególne dobrym wehikułem takiego przekształcenia, ponieważ ich seksualność z trudem poddaje się naturalizującym interpretacjom, zgodnie z którymi seks w naturze jest zawsze heteroseksualny i służy rozmnażaniu. Nie jest to prawda w odniesieniu do zwierząt - zachowania seksualne niesłużące reprodukcji, homoseksualizm czy transseksualizm są wśród wielu ich gatunków zaskakująco częste ${ }^{35}$ - niemniej ich seksualność, podobnie jak seksualność ludzka, pozostaje uwięziona w paradygmacie naturalistycznym, przedstawiającym przyrodę jako domenę instynktów, determinizmu genetycznego i wytwarzanego przez nie porząd$\mathrm{ku}$, mającego być wzorem także dla ludzi. Antynaturalizm widoczny w wielu ujęciach psychoanalitycznych (także u Irigaray) jest tylko odwróceniem naturalizmu i próbą wyrwania człowieka z natury pojmowanej jako domena przerażającej powtarzalności i bezmyślności. Podejście proponowane przez Deleuze'a i Guattariego pozwala nam uniknąć i naturalizmu, antynaturalizmu. „Zarówno botaniczny seks, jak i cielesna różnorodność roślin może [...] z powodzeniem otwierać drogę ludzkim fantazjom oraz inspirować nienormatywne praktyki seksualne" ${ }^{136}$. Co więcej, może to być nienormatywność uwolniona od uwikłania w problematykę winy i transgresji, która poważnie ogranicza radykalny potencjał „perwersyjnych” praktyk. „Jest się wtedy niczym roślina: tworzy się świat lub też stawanie się ze wszystkiego i wszystkich, z całego świata, ponieważ tworzy się świat z konieczności połączony, usuwa się z siebie wszystko to, co przeszkadza nam prześlizgiwać się między rzeczami, przepchnąć się na poziom rzeczy"37.

Nie jest to jednak łatwe zadanie. Ludzka nieświadomość, choć na najbardziej podstawowym poziomie pozostaje wytworzona przez produkcję pragnącą, nie znającą braku i zakazu, na kolejnych poziomach organizacji poddawana jest znaczącemu, prawu i normom ${ }^{38}$. Rozmontowywanie ich

34 Tamże.

35 J. Roughgarden Evolution's Rainbow: Diversity, Gender and Sexuality in Nature and in People, University of California Press, Oakland 2004; M. Hird Zwierzęcy transseksualizm, przeł. J. Bednarek, w: Teorie wywrotowe, red. A. Gajewska, Wydawnictwo Poznańskie, Poznań 2012.

36 M. Bakke Rozkwitajq̨cy seks, s. 48-9.

G. Deleuze, F. Guattari Tysiq̨c plateau, s. 339.

G. Deleuze, F. Guattari Anty-Edyp, s. 27-42; C. Rudnicki Wprowadzenie do lektury Anty-Edypa, "Machina Myśli", http://machinamysli.org/wprowadzenie-do-lektury-anty-edypa/ (8.12.2017). 
to delikatny proces. Jak zatem stawać-się-rośliną, unikając pułapek sprawiających, że na nowo popadamy $w$ winę albo pogrążamy się $w$ autodestrukcji?

Trzeba przede wszystkim pamiętać, że ściśle biorąc, roślina nie jest „niewinna” w sensie braku winy. Kwestia winy i niewinności nie może się w odniesieniu do niej w ogóle pojawić. Stawanie-się-rośliną nie jest zatem dążeniem do niewinności rozumianej jako uwolnienie od winy. Szczególnie jasno ukazuje to Wegetarianka Han Kang. Bohaterka powieści, Yŏng-hye, na pozór przeciętna młoda kobieta (choć od początku nieco podejrzana z powodu swojego introwertyzmu i niechęci do noszenia stanika), pewnego dnia, pod wpływem koszmarnego snu, przestaje jeść mięso i nabiał. Rozpada się jej małżeństwo; rodzina uznaje ją za chorą psychicznie; jej fascynacja roślinami zyskuje charakter seksualny, co sprawia, że bierze udział w perwersyjnym projekcie artystycznym swojego szwagra, filmie przedstawiającym „scenę miłosnego aktu nagich pomalowanych w kwiaty cial"39. W końcu przestaje jeść w ogóle, wierząc, że zmienia się w drzewo. Na pozór to przypadek stawania się - uwalniania się od opresyjnych wymogów społeczeństwa, heteronormatywności i ludzkiej kondycji, zakończony stawaniem-się-rośliną. Nic jednak nie byłoby dalsze od prawdy.

Sen Yŏng-hye, który zmusza ją do wegetarianizmu, dotyczy przemocy i okrucieństwa, nieodłącznych od bycia człowiekiem - a może w ogóle istotą żywą: „Moje dłonie były splamione krwią, moje wargi były splamione krwią. Wcześniej, w magazynie, wkładałam do ust kawałki mięsa, które spadły na ziemię. W dziąsłach i na podniebieniu czułam smak krwi i gąbczaste kawałki mięsa. W kałuży krwi, która zbierała się na podłodze magazynu, zobaczyłam swoje odbicie, swoje błyszczące oczy"40. Pod koniec, umierająca, mówi: „nie jestem już zwierzęciem"41. Bycie rośliną oznacza więc niewinność, życie bez krzywdzenia i zabijania innych istot.

To radykalne poszukiwanie niewinności jest próbą wyjścia z błędnego kręgu wszechobecnej, sankcjonowanej społecznie agresji: próbą wymazania przemocy ze strony męża i ojca, której sama Yŏng-hye doświadczyła czy okrucieństwa wobec zwierząt, którego była świadkiem. W świecie Wegetarianki nawet opieka i ratowanie życia (co widać w przerażających scenach

Han Kang Wegetarianka, przeł. J. Najbar-Miller i Choi Jeong-In, Wydawnictwo Kwiaty Orientu, Skarżysko-Kamienna 2014, s. 54.

40 Tamże, s. 14-15.

41 Tamże, s. 139. 
przymusowego karmienia) wiążą się nierozerwalnie z przemocą ${ }^{42}$. Odmawiające jedzenia ciało staje się polem walki, autodestrukcja - jedynym sposobem na zyskanie godności ${ }^{43}$ czy też próbą spłacenia długu, jaki zaciągamy u wszystkich żywych istot - długu, który spłacić można tylko własną śmierciąa ${ }^{44}$. Dlatego recenzentki porównują tę książkę do Kopisty Bartleby'ego Melville'a i Gtodomora Kafki ${ }^{45}$. Sądzę jednak, że porównanie to ma poważne ograniczenia. Deleuze i Guattari ukazują, w odniesieniu do Kafki i Melville’a, że głodowania i odmowy pracy, a następnie udziału w życiu, będących udziałem bohaterów obu opowiadań, nie należy interpretować jako po prostu autodestrukcyjnych czy stanowiących protest przeciw kondycji ludzkiej, ale raczej jako nieudane procesy stawania się, których wynik - śmierć - wcale nie jest konieczny ${ }^{46}$. Z kolei podkreślana w Wegetariance ciągłość między przemocą w rodzinie, przemocą patriarchatu, przemocą związaną z jedzeniem mięsa i przemocą nieodłączną od życia w ogóle sprawia, że powieść ta staje się niebezpiecznie podatna na konserwatywną interpretację, zgodnie z którą, skoro życie to okrucieństwo i wykorzystywanie innych, nie ma żadnego sensu walczyć z tymi formami okrucieństwa, które są podatne na naszą interwencję (jak chów przemysłowy czy przemoc w związkach intymnych).

Jedyny moment transformacji Yŏng-hye, w którym pojawia się możliwość wyniku innego niż autodestrukcja - opisywana w środkowej części książki historia roślinnej perwersji porywającej bohaterkę i jej bezimiennego szwagra - również pozostaje w ostatecznym rozrachunku określona przez winę, wstyd i autodestrukcyjność. Mężczyzna, choć dość bezwzględnie realizuje swój artystyczno-seksualny projekt, nie przejmując się uczuciami

42 P. Khakpour, 'The Vegetarian,' by Han Kang, "The New York Times", https://www.nytimes. com/2016/02/07/books/review/the-vegetarian-by-han-kang.html (8.12.2017).

43 Han Kang, S. Shin Interview with Han Kang , "The White Review" 2016, http://www.thewhitereview.org/feature/interview-with-han-kang/ (8.12.2017).

44 J. Lee Debt, Payback, And the Sustainability Through the Vegetal Imagination-Atwood's Payback and Han Kang's the Vegetarian, "PEOPLE: International Journal of Social Sciences” 2017 Vol. 3, No. 1.

45 L. Miller "I'm Not an Animal Anymore". Han Kang's mystifying, ecstatic The Vegetarian, "Slate", http://www.slate.com/articles/arts/books/2016/02/han_kang_s_the_vegetarian_reviewed. html (8.12.2017); P. Khakpour 'The Vegetarian,' by Han Kang.

46 G. Deleuze, F. Guattari Kafka. Ku literaturze mniejszej, przeł. A.Z. Jaksender, K.M. Jaksender, Wydawnictwo Eperons-Ostrogi, Kraków 2016; G. Deleuze Bartleby albo formuła, przeł. G. Jankowicz, w: H. Melville Kopista Bartleby. Historia z Wall Street, przeł. A. Szostkiewicz, Sic!, Warszawa 2009. 
(utrzymującej go) żony, jednocześnie nieustannie przeżywa poczucie winy i pogardę wobec siebie. Otrzymujemy więc smutną, żenującą opowieść o męskim egoizmie i zdradzie. Wydaje się, że nie ma tu miejsca na roślinną seksualność - światem Wegetarianki rządzi człowieczeństwo jako wina, od której można uciec tylko poprzez śmierć.

Dzieje się tak być może dlatego, że autorka nie zdecydowała się na wprowadzenie motywów fantastycznych, a przemiana Yŏng-hye zostaje przedstawiona jako choroba psychiczna. W poprzedzającym książkę o dziesięć lat opowiadaniu Owoc mojej kobiety żona, przez całe życie marząca o podróżach i wyrwaniu się z mieszczańskiej stabilizacji, naprawdę staje się rośliną. Mąż nieco sympatyczniejszy niż mąż Yŏng-hye, choć też niewiele rozumiejący - opiekuje się nią, a kiedy wraz z nadejściem jesieni kobieta-roślina umiera, wydając owoce, sadzi je w doniczkach. „Czy moja żona znowu wykiełkuje wraz z nadejściem wiosny? Czy jej kwiaty rozkwitną na czerwono? Nie wiedziałem" ${ }^{\prime 4}$. Fantastyczne rozwiązanie fabularne pozwala na zarysowanie historii bardziej wieloznacznej i nie tak pesymistycznej jak ta przedstawiona w Wegetariance (choć równie przerażającej).

Być może to właśnie fantastyka (co obejmowałoby też horror, klasyczną weird fiction i new weird ${ }^{48}$ ) pozwala na najpełniejsze wprowadzenie do literatury opisywanych przez Deleuze'a i Guattariego procesów molekularnych, a w szczególności stawania się? Teza ta jest może uproszczeniem - klasyczne dzieła modernistyczne Virginii Woolf czy Henry'ego Millera są przecież w Kapitalizmie i schizofrenii ważnym punktem odniesienia. Zajmują jednak miejsce na równi z tekstami H.P. Lovecrafta czy Franka Herberta. Posthumanizm i nowy materializm również inspirują się fantastyką - wystarczy pomyśleć o licznych odwołaniach do SF u Donny Haraway. W jej najnowszej książce, Staying with the Trouble, pojawiają się między innymi odwołania do tekstów Ursuli K. LeGuin, w których główną rolę odgrywają rośliny ${ }^{49}$. LeGuin, posthumanistka avant la lettre, już w latach 70. XX wieku zajmowała się zagadnieniem nie-ludzkiej - zwierzęciej i roślinnej - sprawczości. Pierwsze z opowiadań, Rękopis na ziarenkach akacji, to próba literackiego rozwinięcia refleksji zapoczątkowanej na gruncie

47 Han Kang The Fruit of My Woman, przeł. D. Smith, „Granta Magazine” $2016 \mathrm{nr}$ 133, https://granta. com/the-fruit-of-my-woman/ (8.12.2017).

48 J.A. Weinstock The New Weird, w: New Directions in Popular Fiction, ed. by K. Gelder, Palgrave Macmillan, London 2016.

49 D. Haraway Staying with the Trouble, Duke University Press, Durham 2016, s. 117-119, 121-125. 
nauki przez pionierów biosemiotyki takich jak Thomas Sebeok czy Thure von Uexküll. Stanowiące pastisz tekstu naukowego - wybór materiałów z „Przeglądu Naukowego Towarzystwa Zoolingwistycznego” - poświęcone jest analizom ekspresji artystycznej różnych gatunków zwierząt mrówek czy pingwinów. Okazuje się jednak, że istnieją formy ekspresji jeszcze bardziej obce ludzkim kategoriom - sztuka roślin. „Możemy tyko snuć domysły, że domniemana Sztuka Roślin jest diametralnie różna od Sztuki Zwierząt [...], jest sztuką niekomunikatywną - i prawdopodobnie niekinetyczną. [...] [K]iedy ją odkryjemy, okaże się nie akcją, ale reakcją, nie komunikowaniem się, ale percepcją. Będzie to dokładne przeciwieństwo sztuki, którą znamy i potrafimy rozpoznać"50.

Rośliny stanowią zatem ucieleśnienie obcości znacznie bardziej dogłębnej niż obcość zwierzęca - roślina to obcy par excellence ${ }^{51}$. To istoty żywe, ale nie poruszające się - czy raczej poruszające się tak wolno, że ludzkie oko na ogół tego nie rejestruje, funkcjonujące na innej skali czasowej niż ludzie ${ }^{52}$. Dlatego sprawiają wrażenie jednocześnie ożywionych i nieożywionych. Ta dwuznaczność, a także potworność nieskończonego wzrostu ${ }^{53}$ może czynić je dla nas źródłem efektu niesamowitości ${ }^{54}$. Choć drugie wspomniane opowiadanie LeGuin, Szerzej niż imperia i wolniej, nie jest horrorem, wykorzystuje ten efekt, by zadać pytanie o roślinną świadomość.

W tym należącym do cyklu Hain tekście wysłana na rubieże znanej części kosmosu ekspedycja badawcza - w której skład wchodzą wprawdzie przedstawiciele i przedstawicielki gatunków odmiennych, ale humanoidalnych i mało się od siebie różniących - dociera na planetę 4470, zamieszkaną wyłącznie przez rośliny i dlatego uznaną przez nich za „bezludną”. Wydaje się, że jedynym problemem odkrywców będzie dynamika wewnątrzgrupowa: jednym z członków wyprawy jest hiperempata Osden, który potrafi zarówno odbierać uczucia otoczenia, jak i projektować je z powrotem. Dar ten jest jednak dla niego przekleństwem, ponieważ nie potrafi go „wyłączyć”. Dlatego podświadomie broni się przed falą napierających na niego emocji,

50 U. LeGuin Rękopis na ziarenkach akacji, przeł. B. Kluczborska, w: Dziewczyny Buffalo i inne zwierzęce obecności, Wydawnictwo Alkazar, Warszawa 1993, s. 218-219.

A. Trewavas Aspects..., s. 1; M. Bakke Rozkwitający seks, s. 51.

M. Marder Plant-Thinking, s. 107. 
wychwytując te negatywne i projektując je w stronę osób, które mu towarzyszą - budzi więc we wszystkich niechęć. Między członkami ekspedycji powstaje więc swego rodzaju emocjonalny rezonans intensyfikujący strach, paranoję i nienawiść. Co więcej, po pewnym czasie okazuje się, że nie jest to tylko ich dzieło: oprócz nich na planecie jest i inna przerażona świadomość, jednak tak odmienna od tych, do których są przyzwyczajeni, że z początku nie chcą uznać jej istnienia.

Chodzi oczywiście o porastające planetę rośliny, tworzące jeden system - hiperorganizm, który dotąd nie zetknął się z odmiennymi formami życia, funkcjonował bez swojego Innego. „Świadomość bez zmysłów. Ślepa, głucha, pozbawiona nerwów i ruchu. Tylko pewna wrażliwość, reakcja na dotyk. Reakcja na słońce, światło, wodę i minerały w ziemi otaczającej korzenie. Coś niezrozumiałego dla zwierzęcego umysłu. Obecność bez umysłu. Świadomość istnienia bez przedmiotu i podmiotu. Nirwana" ${ }^{15}$. Nic dziwnego, że obecność osobliwych, szybko się przemieszczających istot budzi w nim panikę. Jak jednak skomunikować się z tym bytem i przerwać błędne koło strachu, który stopniowo doprowadza wszystkich do szaleństwa? Komunikacja dyskursywna jest wykluczona - jedynym językiem, który rozumie nasza istota, są emocje. Dlatego Osden decyduje się przyjąć na siebie wszystkie emocje monstrualnej roślinnej istoty - i, być może, przekształcić je w emocje pozytywne. Oczywiście mu się udaje i strach znika. Odkrywcy mogą zakończyć badania i wracać do domu - on jednak woli zostać: „Osden przyjął w siebie cały strach, przyjął go i pokonał. Oddał siebie obcej istocie i była to bezwarunkowa kapitulacja nie zostawiająca miejsca na zło. Nauczył się darzyć miłością kogoś innego i dzięki temu odzyskał samego siebie"56.

Mamy zatem do czynienia z historią miłosną. Można by uznać, że chodzi raczej o miłość jako agape niż jako eros - ale czy musimy trzymać się takich podziałów, utrwalających wizję seksualności jako zjawiska genitalnego, oddzielonego od reszty życia? Tytuł opowiadania to wers z wiersza Andrew Marvella Do nieskorej bogdanki, w którym podmiot liryczny zachęca kochankę zwlekającą ze skonsumowaniem związku, żeby się pospieszyła, ponieważ ludzie, w przeciwieństwie do drzew, nie mają zbyt wiele czasu. Gdybyśmy byli roślinami, mówi, „roślinna miłość we mnie by wzrastała / Większa od

\footnotetext{
55 U.K. Le Guin Szerzej niż imperia i wolniej, przeł. L. Jęczmyk, w: Dziewczyny Buffalo..., s. 149-150.

56 Tamże, s. 162.
} 
królestw, bardziej od nich trwała"57. To przeciwstawienie roślinnej długowieczności i ludzkiej ulotności dobrze wpisuje się w mistykę (hetero)seksualności jako zjawiska dostępnego wyłącznie ludziom, nieodłącznego od braku i ciągłego niezaspokojenia; LeGuin pokazuje jednak, że w pewnych sytuacjach, pod pewnymi względami, możemy stać się roślinami - „roślinna miłość" pozostaje w naszym zasięgu, co oznacza też, że nie musimy zawsze być wyłącznie ludźmi. Być może ceną za to jest utrata osobistej tożsamości ${ }^{58}$ - czy jednak jest ona zbyt wysoka?

Proponowana przez LeGuin wizja roślinnej świadomości jako pozbawionej rozróżnienia na podmiot i przedmiot, jednolitej i biernej jest jednak, w obliczu nowszych badań nad komunikacją roślin, zbyt jednostronna ${ }^{59}$. Badania dotyczące porozumiewania się roślin, czy to za pomocą sygnałów chemicznych uwalnianych do atmosfery, czy za pośrednictwem sieci mikoryzowej (określanej jako Wood Wide Web) ${ }^{60}$ wskazują raczej na to, że ziemskie rośliny, w przeciwieństwie do tych z planety 4470, tworzą wiele systemów świetnie skomunikowanych, ale nieprzekształcających współtworzących ich organizmów w jednorodny system; pojedyncze rośliny mają własne interesy ewolucyjne, a symbioza stanowi sposób na ich realizację (choć bywa też, że nie da się zaobserwować takich korzyści, co pokazuje, że natura pozostawia sporo miejsca na przygodnośćc6 ${ }^{61}$. Rośliny nie żyją zatem pogrążone w stanie nirwany, nie są (jak bogowie) wzorem szczęśliwości niedostępnej ludziom² ${ }^{62}$. Są bardzo od nas różne, ale - jako żywe istoty - pod pewnymi względami podobne.

Natura, nadal będąc radykalnie odmienna, nie pełni już funkcji konstytutywnego innego Człowieka. Oto prawdziwy demontaż antropocentryzmu.

57 A. Marvell Do nieskorej bogdanki, przeł. S. Barańczak, w: tegoż 24 wiersze. Poems, Wydawnictwo Literackie, Kraków 1993, s. 65. Aluzja niestety umyka w polskim przekładzie opowiadania.

58 U. Heise Sense of Place and Sense of Planet, Oxford University Press, New York 2008, s. 20. Por. I. Watson The Forest as Metaphor for Mind: "The Word for World is Forest" and "Vaster Than Empires and More Slow", "Science Fiction Studies" 1975 Vol. 2, No. 7, https://www.depauw.edu/sfs/ backissues/7/watson7art.htm (8.12.2017).

59 Opowiadanie zostało opublikowane po raz pierwszy w 1971 roku; pierwsze hipotezy na temat komunikowania się roślin wysunięto w latach 80.; zob. J. Goodall Mądrość i cuda świata roślin, przeł. D. Cieśla-Szymańska, Marginesy, Warszawa 2017, s. 52. S.W. Simard et al. Mycorrhizal networks: Mechanisms, ecology and modelling, „Fungal Biology Reviews" 2012 Vol. 26, No. 1. 
Współczesna fantastyka, zwłaszcza ta spod znaku ekohorroru czy też anthropocene fiction ${ }^{63}$ stawia w centrum swojego zainteresowania właśnie problematykę natury, zdenaturalizowanej zarówno przez praktyczne ludzkie ingerencje w nią, jak i nowe podejścia teoretyczne rezygnujące $\mathrm{z}$ dualizmu natura-człowiek, oraz człowieczeństwa, również zdecentralizowanego i zakwestionowanego przez wymienione zjawiska. Jednym z najsłynniejszych przykładów tego nurtu jest trylogia Southern Reach Jeffa VanderMeera. Ściśle mówiąc, nie przyznaje ona centralnej pozycji roślinom - ponieważ w Strefie X, oddzielonym od reszty świata obszarze niewiadomego pochodzenia, granice między królestwami, typami, rodzajami i gatunkami zostały zatarte.

W pierwszej części, zatytułowanej Unicestwienie, oglądamy ją oczami członkini ekspedycji złożonej (prawdopodobnie celowo) z samych kobiet, znanej po prostu jako biolożka. Southern Reach, agencja organizująca ekspedycje, zniechęca do używania imion. Dla biolożki nie ma to jednak zbytniego znaczenia - to aspołeczna obsesjonatka żyjąca swoją pracą, która zawsze czuła się lepiej w towarzystwie badanych przez siebie organizmów niż ludzi; "czyni ją to dobrą biolożką, ale kiepską istotą ludzką"64. Podobnie jak Osden jest więc podmiotem nienormatywnym czy wręcz nienormalnym, i dlatego szczególnie podatnym na stawanie się. Od początku odczuwa fascynację Strefą X i pokrewieństwo z nią - mimo niepokojących sygnałów świadczących o tym, że nie obowiązują w niej ziemskie prawa natury, że jest ona - choć sprawia wrażenie obszaru nieskazitelnie czystej natury - miejscem znormalizowanej perwersji, wytwarzającym symulakra i hybrydy: sobowtóry członków poprzednich ekspedycji, rośliny zbudowane z ludzkich komórek, zwierzęta o ludzkim spojrzeniu, wieżę, która oddycha, grzyby układające się pismo. To ostatnie zjawisko, istotowe dla funkcjonowania Strefy X, wskazuje na biosemiotyczny charakter jej działań - jej znaki są organiczne, a wytwarzane przez nią hybrydyczne organizmy sposobem komunikowania się $e^{65}$.

63 A. Pilsch Worlds Without Us. The Horror of Indifference in The Southern Reach Trilogy, The Society For Literature, Science, and the Arts 2015 Conference, Houston, TX 2015, http://oaktrust.library. tamu.edu/handle/1969.1/159123 (7.12.2017).

64 S. Booth Magnone Human Contamination. The Infectious Border Crossings of Jeff VanderMeer's Area X, "Somatosphere", http://somatosphere.net/author/sophia-booth-magnone (7.12.2017).

65 G. Ulstein Brave New Weird: Anthropocene Monsters in Jeff VanderMeer's The Southern Reach, "Concentric: Literary and Cultural Studies" 2017, marzec, http://www.concentric-literature.url. tw/issues/The\%20City\%20and\%20the\%20Anthropocene/5.pdf (7.12.2017), s. 20. 
Choć nigdy nie otrzymujemy od autora pełnego rozwiązania zagadki Strefy X, tylko kolejne niejednoznaczne tropy, na podstawie kolejnych części możemy wnioskować, że jest ona pochodzenia pozaziemskiego i zmienia również prawa fizyki, nie tylko biologii. Wynikiem jej działania jest odtworzenie zniszczonego przez ludzi środowiska naturalnego - ale w szczególny sposób, obejmujący nie kres, a spotęgowanie typowego dla antropocenu mnożenia potworów ${ }^{66}$, na skalę, o której ludziom nawet się nie śniło. Słowami biolożki, Strefa X „[t]worzy z ekosystemu nowy świat obejmujący zupełnie inne procesy i cele - świat, który działa za pośrednictwem wyjątkowych aktów odzwierciedlania, pozostaje w ukryciu na wiele różnych sposobów i ani na chwilę nie poddaje swej inności, gdyż staje się tym, co napotyka"'

$Z$ początku niewielka, Strefa X poszerza się stopniowo; wysyła także poza swój obręb klony/sobowtóry członków kolejnych ekspedycji. Logika odzwierciedleń, sobowtórów i symulakrów rządzi zresztą wszystkimi trzema książkami, zarówno na poziomie tematów, jak i obrazowania; opisana w mocno kafkowskiej części drugiej agencja Southern Reach wydaje się całkowicie "zarażona” absurdem charakterystycznym dla obiektu swojego badania, tak, że stanowi jego odbicie ${ }^{68}$. Pod koniec trylogii pochłania (prawdopodobnie) cały świat. Southern Reach nie jest jednak opowieścią apokaliptyczną. Choć zarażenie całego świata potworną logiką Strefy X oznacza koniec świata, jaki znamy, a na pewno koniec ludzkości, nie chodzi o zagładę, a raczej o transformację; „Strefa X zmusza gatunek ludzki, by stał się częścią potwora za sprawą osobliwej [weird] artykulacji"69.

Dla części bohaterów to katastrofa. Ale, jak można się domyślić, nie dla biolożki: jak mówi, „nie mogę [...] z przekonaniem nazwać tego czymś złym. Nie - gdy patrzę na nieskażoną przyrodę Strefy X i porównuję ją ze światem, który tak bardzo przeobraziliśmy"70. Kobieta, która przez przypadek (?) wciąga do nosa zarodniki wspomnianych grzybów tworzących słowa, przechodzi pod ich wpływem przemianę - stopniowo przestaje być człowiekiem. Człowieczeństwo nie jest jednak dla niej szczególnie ważne; chce „przeżyć

66 B. Latour Love your Monsters, "The Breakthrough" 2012 No. 2, https://thebreakthrough.org/index.php/journal/past-issues/issue-2/love-your-monsters (7.12.2017),

67 J. VanderMeer Unicestwienie, przeł. A. Gralak, Wydawnictwo Otwarte, Kraków 2014, S. 223.

68 Tamże.

69 G. Ullstein Brave New Weird, s. 21.

70 J. VanderMeer Unicestwienie, s. 225. 
w Strefie X; nie obchodzi ją jednak, jako co przeżyje"71. Dlatego staje się swego rodzaju emisariuszką Strefy X, przyspieszającą jej ekspansję; dokonuje tego w podwójnej postaci, jako pozostający w Strefie oryginał, który spotykamy w końcu pod postacią przemieszczającego się między wymiarami potwora, jak i przewyższający wszystkie poprzednie klon/sobowtór, który trafia do zewnętrznego świata.

A miłość? Unicestwienie to m.in. nieco dziwna historia miłosna - konkretniej, małżeńska. Biolożka trafia do Strefy X powodowana zainteresowaniem osobliwymi ekosystemami, ale także z powodów osobistych - jej mąż brał udział w poprzedniej ekspedycji. Ich małżeństwo - związek mężczyzny towarzyskiego i komunikatywnego oraz introwertycznej i mało emocjonalnej kobiety, z czasem coraz bardziej oddalających się od siebie - było właściwie porażką. A jednak gdy biolożka znajduje w Strefie X porzucony dziennik męża, okazuje się on listem miłosnym do niej. Decydując się pozostać w Strefie i przejść przemianę do końca, ma nadzieję nie tylko porzucić człowieczeństwo, ale i odnaleźć męża - w jakiejkolwiek postaci, gdyż prawdopodobnie on również przestał być człowiekiem: „Nie liczę na to, że go znajdę - nie muszę go znaleźć - ale chcę zobaczyć to samo co on. Chcę poczuć jego bliskość, jakbyśmy byli w tym samym pomieszczeniu. I jeśli mam być szczera, nie mogę się pozbyć wrażenia, że nawet jeżeli uległ całkowitej przemianie, nadal gdzieś tutaj jest - w oku delfina, w dotyku pnącego się mchu, gdziekolwiek i wszędzie"72. Jest tak, jakby ich relacja mogła zaistnieć jedynie za cenę porzucenia nie tylko heteroseksualności, ale i samego człowieczeństwa czy wręcz podmiotowości, zapośredniczona przez Strefę X, wymagającą od nich - podobnie jak zjednoczenie z roślinnym hiperorganizmem od Osdena - wyzbycia się jednostkowej tożsamości.

Straszne? Pewnie tak. Sądzę jednak, że zwykła, heteronormatywna seksualność i życie zgodnie z nakazami systemu płci kulturowej są dużo straszniejsze. Potworność roślinnego, nie-ludzkiego, niepodmiotowego pragnienia ma inny charakter niż potworność upłciowionego człowieczeństwa. Jak podsumowują Deleuze i Guattari: „Nieświadomość jest potworna, ale jej okrucieństwa nie są antropomorficzne"73. Stawanie-się-rośliną, choć trudne i przerażające, pozwala na odejście od „normalnej” organizacji podmiotowości

S. Booth Magnone Human Contamination.

J. VanderMeer Unicestwienie, s. 227. 
i pragnienia, „pozwala sprowadzić się do linii abstrakcyjnej, do konturu"74 - czyli wydobyć się z antropocentrycznej izolacji, unikając zarazem naturalistycznego redukcjonizmu.

\section{Abstract}

\section{Joanna Bednarek}

INDEPENDENTSCHOLAR

'Drunkenness as a Triumphant Irruption of the Plant in Us': The Promises and Dangers of Plant Sexuality

Bednarek reconstructs the concept of 'plant sexuality' in Deleuze and Guattari's Capitalism and Schizophrenia. This concept was initially seen in relation to the alternative that the two theorists proposed to the oedipal organization of desire and subjectivity. With the humanities' turn towards plants, however, it takes on a new significance and challenges us to ask questions about the definition of nature and the role of human and non-human agency in the anthropocene. Examining representations of the desire for plants or the desire for becoming-a-plant in the works of Han Kang, Ursula K. Le Guin and JeffVanderMeer, Bednarek identifies both the criteria for speaking of plant sexuality and the consequences this has for our notion of humanity.

\section{Keywords}

Deleuze, Guattari, becoming-a-plant, Han Kang, Ursula K. Le Guin, Jeff VanderMeer 